\title{
PRECEDENT PHENOMENAS IN MUSIC INTERPRETATION
}

Siuta B. O.

\section{INTRODUCTION}

Studies of the precedent phenomenas in proection on the nature, features and functions of the speech genres in music are conducted in European musicology on a minimal scale. In fact, only some authors clearly articulate the name of the object of our research in the context of studying other theoretical problems ${ }^{1}$. More often, they only state the existence of precedent phenomenas or genres of musical speech without in-depth development of the related cultural, communicative, socio-psychological, receptive-and-style issues $^{2}$. This is against the background of a great deal of research in the creative (artistic) genres in music and structural features of musical language. Only some researchers interpret the nature of precedents and only distinguish between categories of musical language and speech, but they also give the latter a bit of attention ${ }^{3}$. Therefore, the deepening study of issues of precedent phenomenas and speech genres in music in connection with certain aspects of the precedent theory, which is proposed in our article, is in fact one of the first musicological studies in this research field.

The purpose of the proposed article is to prove the dependence of the plurality of readable contents of musical compositions on the variability of the speech and genre interpretation of the verbal text as a precedent phenomena, which is the basis of the works.

In the history of music, there are many vocal works in which different authors voice the same verbal text. There are also works in which different verbal texts are accompanied with the same music. These are essentially the phenomena of the same order, and the technique of their creation is known as counterfeit. In this article, we will analyze the mechanisms of variability of the precedent text interpretation (which is the verbal component of works)

\footnotetext{
${ }^{1}$ Слышкин Г.Г От текста к символу: лингвокультурные концепты прецедентных феноменов в сознании и дискурсе. Москва : Академия, 2000.

${ }^{2}$ Беліченко Н.М. Структурна поетика музичного твору (на матеріалі музики сучасних композиторів 80-х років. Автореферат дисертації на здобуття наукового ступеня кандидата мистецтвознавства. Київ, 1992. С. $10-11$.

${ }^{3}$ Сюта Б. Мовне поняття жанровий тип у термінологічному корпусі теорії музики. Současné slovanské jazyki a literatury: tradice a současnost. Olomouc, p. 159-167.
} 
in the context of the changeable use of musical speech genres and their variant combinations. In addition to using certain aspects of the methodology of the interpretative mechanisms of precedent texts and names analysis, which is developed in the works by D. Hudkov', Yu. Karaulov, N. Kuzmina ${ }^{6}$, H. Slyshkin ${ }^{7}$, Yu. Sorokin ${ }^{8}$, we'll compare the composers' interpretation of precedent statements and their transformation in newly created musical-and-poetic works.

The fact of artistic variability of musical-and-poetic compositions written for the same poetic text, as well as variability of their semantic concept, is noted by all researchers of such works. While pointing to the overwhelming persuasiveness of the final artistic results of the cooperation of poetry and music, the researchers do not, however, reveal the mechanisms that allow such variability in the composers' interpretation of precedent verbal texts in musical works. The understanding of the nature and functioning of these mechanisms is the main task of our research. We will focus on the study of precedent statements and will find out the role of speech genres in the process of variation of precedent text musical interpretation.

To accomplish these tasks, let us briefly analyze a group of demonstrative musical-and-poetic compositions created on the basis of a single poetic precedent text. This text is the voiced (and extremely popular in the nineteenth century) poetry of Johann Wolfgang von Goethe taken from his famous novel "The Years of the Study of William the Master". This is the Mignon's song "Do you know the land?.." (in the original "Kennst du das Land?”).

\section{Characteristics of the original poetic text, taking into account the implied by the author of his musical speech features}

As it was pointed out by one of the researchers of Mignon's songs in I. Drach's music (a small propedeutical work by J. Arbogast devoted to the performing aspects of Mignon's Song is available online): "Goethe had a great idea of how these songs should sound. The novel contains detailed

4 Гудков Д.Б. Прецедентное имя и проблемы прецедентности. Москва, Издательство МГУ, 1999.

${ }_{6}^{5}$ Караулов Ю.Н. Русский язык и языковая личность. Москва : Наука, 1987.

6 Кузьмина Н.А. Интертекстуальность и прецедентность как базовые когнитивные категории дискурса. Медиастилистика. Вып. 1. URL: www.mediascope.ru/node/755.

${ }^{7}$ Слышкин Г.Г. Линвокультурные концепты прецедентных текстов. Москва : Академия, 2000; Слышкин Г.Г. От текста к символу: лингвокультурные концепты прецедентных феноменов в сознании и дискурсе. Москва : Академия, 2000.

8 Сорокин Ю.А. Психологические аспекты изучения текста. Москва : Наука, 1985. 
descriptions of the intonation of the poems (it refers to the "solemn grandeur" at the beginning of the song, which is almost absent in all musical versions of the song by the Romanticists, as well as to the "somber and sad tune" of the recurring question "Kennst du es wohl?" or "mystery and gloom" of the call "Dahin! Dahin ... ziehn", rendered in only a few compositions. - B. S.). Therefore, the composer's initiative, which wrapped the poet with a wave of vocal arrangements of his songs, did not cause him delight. "To depict with sounds the thing which itself sounds, thunders, drums, pours into a tank of sounds - is disgusting. A minimum of this can reasonably be used to sort things out" - Goethe wrote to one of the musicians"'.

Then, the researcher in a musical-and-publicistic sense describes some of the most famous musical-and-poetic compositions based on the Mignon's song, created by L. Beethoven, F.P. Schubert, R.A. Schumann, F. Liszt, C.L.A. Thomas, P. Tchaikovsky. The author vividly depicts their artistic order, nature and lyricism. But in her work there is no mention of the reasons for the diversity of musical interpretations of poetry and the correlation of the musical-and-poetic variant with the "sound-vision" of the author of the precedent text. Even the diversity of rhythmic embodiments of musical "readings" and the magnitude and temporal commensurability of musical and poetic utterances (including repetitions of separate phrases and words) did not interest the author. However, this is no accident. After all, in the traditional methodology of musicological research, the tools for such operations have simply not been developed. We propose the only, in our opinion, productive method of analysis that can not only describe works and point out differences, but also justify ways to achieve a particular artistic effect in the poetry, which is put on music. It is based on the study of transformations and modulations of musical speech genres and their modalities.

First, let us carefully read the text of the analyzed first song of Mignon by Johann Wolfgang von Goethe (1784). We'll consider, first of all, the original German text to clarify the types and structure of the speech genres involved:

Kennst du das Land? wo die Citronen blühn...

Kennst du das Land? wo die Citronen blühn,

Im dunkeln Laub die Gold-Orangen glühn,

Ein sanfter Wind vom blauen Himmel weht,

Die Myrte still und hoch der Lorbeer steht,

Kennst du es wohl?

Dahin! Dahin

Möcht' ich mit dir, o mein Geliebter, ziehn.

\footnotetext{
${ }^{9}$ Драч И. Странствия Миньон. URL: http://jgreenlamp.narod.ru/minjon.htm.
} 
Kennst du das Haus? Auf Säulen ruht sein Dach,

Es glänzt der Saal, es schimmert das Gemach,

Und Marmorbilder stehn und sehn mich an:

Was hat man Dir, du armes Kind, gethan?

Kennst du es wohl?

Dahin! Dahin

Möcht' ich mit dir, o mein Beschützer, ziehn.

Kennst du den Berg und seinen Wolkensteg?

Das Maulthier sucht im Nebel seinen Weg;

In Höhlen wohnt der Drachen alte Brut;

Es stürzt der Fels und über ihn die Flut.

Kennst du ihn [by F. Schubert - es] wohl?

Dahin! Dahin

Geht unser Weg! o Vater, laß uns ziehn!

In this song the poet used the speech genre of appeal in the modality of a question as the basic and hierarchically the highest one. It is inextricably linked to the genres of the story ("ingrown" into the main question, which is verbalized in the first five lines of each verse), the call (the last phrase of the verse), and the explanation with the elements of exclamation (the last two lines of each verse). The outline of the creative genre of poetry - a song - is of musical origin and appeals to the musical-and-communicative realities and intonational specifics of reproduction.

All three verses of the song have the same structure in terms of the genres used. The first four lines are considered to be a rhetorical question, visually enhanced by the additional question mark used in the first line. The fifth, incomplete line is a repeated question, which is less rhetorical in modality. The last two lines in the form of an exclamation express the desire to get to that land (the last verse contains the call-request in the final line of the poetry: "Oh father, let's go there!". The last word of the line is absolutely phonically assonant with the last word of the previous two verses).

\section{Transposition of speech genres used in Goethe's poetry into professional musical communication}

The question is: How is this mix of genres reflected in music? We have considered a number of the most significant vocal-and-poetic works, which are based on the described poems by Goette. They all date back to the 19th century, when the ideas of romance experienced a time of the highest flowering in the art of European countries. These are the works of L. Beethoven (op. 75 No. 1, composed in 1810), L. Spohr (op. 37 No. 1, written and published in 1815), F. P. Schubert (op. 62 D 321; both versions 
written in 1815, published in 1832), R. A. Schuman (op. 98 A, written in 1849), by F. Liszt (S. 275, three versions: 1842, 1854, 1860), by H. Wolf (IHW 10, written about 1875, printed in 1889). Only fragmentally we involved into consideration the very popular compositions by P. Tchaikovsky (Six Romances, op. 25 № 3) - because of the considerable deformation in this romance of the speech parameters of verbal precedent text in replay of F. I. Tyutchev and A. Rubinstein (op. 91 № 4 for soprano accompanied by piano from the cycle "Poems and Requiem for Mignon"). Here even the precedent genre in the epitextual position was changed from songs to "poems", which caused irreversible modulations of the used genres of speech. By similar features the Mignon's song "Kennst du das Land?" (No. 15 from the 4th Notebook "Śpiewnik-a") is characterized. Its Polish translation was put to music by S. Moniushko (in $1870 \mathrm{~V}$. Bessel published this work in St. Petersburg with the Russian text only). The compositions to the text of the Goethe's song of Mignon, made by V.I. Glavach, E.Yu. Goldshtein, E.Ya. Dlusskij, A.M. Alferaki, D.A. Usatov, V.I. Suk, P.I. Blaramberg (in various translations into Russian) were also widely known, but now they are practically forgotten.

One of the earliest examples of the Mignon's song, "sounded" by the composer, is considered to be the work of L. Beethoven op. 75 № 1. As the main musical-and-speech genre of this composition, L. Beethoven chose a quiet and moderate ... march (in size 2/4; the rhythmics of the musical speech of the song is fully synchronized with the dactyl of poetry). Musical phrases are symmetrical in rhythm and duration to the phrases of poetry. Nevertheless, in the division of utterances prevails the logic of unfolding a musical-andharmonic nature rather than a verbal-and-plot one. In this case, very logical and stylistically justified are the stops of the interrogative statements on the dominant harmony (in the 4th, 7th and 17th beats). True, this clearly directs the listener to dominance in the work of the laws of the development of instrumental music of Classicism. The sixth and the seventh verses of each stanza (in poetry - appeal) are organized by the composer as a refrain. They are created in the speech genre of a moderately fast double-beat dance in the style of Sicilian (beats 18-32, 50-64, 82-97 + 1; rate is changed onto 6/8 (also double-beat as the previous marching), the tempo from the rather slow Ziemlich langsam - onto Faster), and the melodious phrases become longer and more rounded. The modality of the call is modeled due to the iambic upbeat beginning of each phrase (as opposed to the affirmative nature of the choree rhythm in two-quarter phrases of the verse). However, this approach is typical for classicists, but it is not very effective in terms of art: the music sounds rather sluggish. The vivid symmetrical structure of the work (three equal verses with a final refrain-call-dance) does not contribute to the creation of a particularly elevated romantic mood and atmosphere of impulse embodied 
in the call. It is broken only in the last (!) beat of the work, that serves as the final tonic point in this story.

An interesting and subtle musical technique of using the question genre in the song is the constant stressing of the first line of the stanza on the words "Kennst du ..." by ascending and close to the intonation of the question motive that further needs (and receives!) a descending solution-answer (or explanation). Minimal texture developing variation cannot overcome the static nature of the chosen speech-genre structure. Although the composer finds an interesting lively means of development: the major beginning is changed in all stanzas into a minor one to end again with a refrain in major. However, the chosen speech genres of poetry and music still do not resonate harmoniously: poetry here is clearly "adjusted" to the musical component of utterances, which causes its emotional simplification and elimination of the energetic impulse. The melody is interpreted in its development more instrumentally than vocally. Obviously, these features have caused the moderate popularity of this Beethoven's work among contemporary performers, though it has the reputation of being his best lyric song.

In Schubert's "Mignon", the customary rhythm of a moderate movement does not become as dominant as in L. Beethoven's work. Strangely, the tonal-and-harmonic development of the verse verse in F. Schubert coincides with the Beethoven's one. But the music reflects the motive turns of the poetic utterances much more subtly, each question is reflected in much shorter and more intonationally flexible musical phrases, devided by more tangible censorship (in tacts: $2+2+2+3+3+2$ (instr.) +2 ). The structure of the verse loses a certain amount of the classical symmetry, but it fits completely into the possible domination at the highest level (also in interpretation of the verbal component) of the features of a conversationstory speech genre.

In the refrain (beats 19-40), the composer gradually but unambiguously directs the listener to the last phrases, which, like in poetry, are modeled in the genre of exclamation-clarification. The intention of desire that ends intonationally at the highest climax sound $\mathrm{a}^{2}$, which is the tonic of the main tonality, seems to hang on the delayed pause that completes the first refrain. The listener awaits further verses of the same kind with verse - refrain. The second stanza is completely identical to the music of the first. The third (beats 41-59 + 60-81) becomes the logical center of the work. The speech genres used are completely the same. But if in the first verse predominated a fascinating expression in the modality of the question, here the music is focused on the story of something too unusual and fantastic. This is well accentuated by the use of the eponymous minor and the simultaneous isolation of the third verse into a kind of semantic climax of the form. The refrain is repeated three times without textural and harmonic changes, enhancing the 
author's emotionality in the text. In addition, the expressiveness of the involved speech genres is enhanced by the repetition of verse appeals-calls used by the composer. The composer convincingly adheres to the strophic structure of the work, emphasizing the stages of dramatic development with laconic interacts between poems. Despite the enormous influence of L. Beethoven's "Mignon's song" both in rhythmic structure and in the construction of melodic phrases, F. Schubert's composition with its original character and thought-out dramaturgy is perhaps closest to the poet's ideas about the musical interpretation of the poems.

Almost simultaneously with F. Schubert, his famous contemporary Louis Spohr also created "The Song of Mignon". It opened his cycle of Six German Songs Op. 37, concluded in 1815, and was a huge success in the nineteenth century. This work was well known by Johann Wolfgang von Goethe, who characterized L. Spohr's music as the example of "entire misunderstanding" of his poetry. This is not surprising, because in Spohr's song we find neither emotional appeal nor rhetorical question, there is no feeling of longing for the native land, there are practically no intonations of the call. This is a typical lyrical epic story. As it was intended by the composer, epic features in the style of mythical Ossian songs should be supported by texture of accompaniment, which is created in the form of quasi-harp arpeggio chords (let's recall the Goethe's Harpist from "The Years of Study of William the Master"). It is also worth mentioning that Goethe's "Mignon's song" is actually a parody of James Thomson's English ballad "Summer" (compare lines 663-671 of this ballad with Goethe's lyrics), written in 1746 and still well known in Germany in the early nineteenth century. In this song, the melody of wide breathing totally predominates. Only in the climax zone of this epic tale (the point of golden division at the beginning of the third stanza) it slightly imitates the agitated appeal, after which the rounded melodic phrases of the epic tale come back again. The strophic poetry of precedent text receives a through dramaturgy, characteristic of the epic story genre. This fact brought it closer to the specifics of the development of music of instrumental genres and complicated the perception of the work by the listener. Of course, such modulation of the speech genres of poetry in music was disliked by Goethe, who both in Beethoven and Spohr wanted to see more a folk song, but not an aria. It also did not contribute to persuasiveness of musical interpretation of his poetry. This eventually led to the gradual departure of the Mignon's song from the foreground of the vocal masterpieces of the Romantic era to its far margins.

Ferenc Liszt, voicing Goethe's poems, read a precedent text, revealing in it the traits of sensuality, emotionality, exoticism. There are three editions of Liszt's "The Song of Mignon" (the first one - for high voice and piano). The huge popularity of the first edition was not least due to its author's arrangements for piano solo, which F. Liszt often performed as a pianist. It is 
interesting to observe how the composer, creating new versions of the song, tries to get closer in sound and meaning to Goethe's original (the vast majority of works by F. Liszt exist in several editions). It is worth noting that Ferenc Liszt spoke many European languages and tried to convey their specifics in the vocal works to the original texts (he wrote eighty-two songs, fifty-two of which were written on the German poems, fourteen - on French, five - on Italian, three - on Hungarian, one - on Russian and twelve - on the English ones). Sometimes, this was not quite successful, so the songs were constantly improved. The third (second edition is a simple version of the first, modified for mezzo-soprano and piano) edition (1860) features four beats of instrumental introduction. The intonations of the introduction with the characteristic descending tritonic motif become a kind of "leit expression", which marks all the main stages of the song's plot development. The seemingly unambiguously ascending intonation of the question becomes in Liszt's work a descending one, adding to that question a touch of rhetoric.

This insightful lyrical song belongs to a few Ferenc Liszt's works of the stanza structure. It demonstrates a vivid desire to use the expressive potentiality of the speech genres: each stanza contains a question, which is subsequently intensified and - finally - becomes an expression of a melancholy sigh. The intensity of desire increases towards the third refrain. The melody moves more steadily with simultaneous movement down along the voice range, which makes the utterance more dramatic. The culminating sounding on the word "Vater" is emphasized by the fermata-detention. This is similar to the hanging detentions "la $\beta$ " in Beethoven's "Mignon". The deliberately impregnated repetition of "Dahin!" completes the work, gradually fading away.

In order to make the genre's possibilities of speech more expressive, Liszt takes a closer look at the sounding of poetic rhythm. Thus, in the first edition of "Mignon", the word "Du" found itself on a metrically strong beat. As a result, a logical emphasis of the phrase has shifted, leveling the content of poetry. This mistake was later successfully corrected in the third version of the song: the question "Kennst" attracted the main attention by lengthening the silaba's sounding by means of formation of an inter-beat syncope. It smoothed out the unwished accent and "moved" the silabalexeme "Du" to the weaker second beat. The nature and the degree of expression of the musical version of the song changed greatly, and the genre of question became dominant in the song, rising to a higher level. No composer before Liszt made such a distinction of speech genres by levels. Accordingly, the structure of all musical phrases-utterances has been transformed. Using expressive resources of tonal-and-harmonic, as well as texture and voice colours, the composer appropriately enhanced the song's 
expressive line with modalities of nostalgia and desire, which harmonized well with the speech genres used in poetry and synchronized with the dramatic center of this poetry. The first edition of the work was often criticized by the contemporaries (e.g., the disdainful commenting on this Liszt's work in the articles by G. Larosch) for its purely timbre-sweet beauty of instrumental nature. However, the third edition is considered one of the best romantic songs of the XIXth century.

In Robert Schumann's creative work, "Kennst du das Land?" is the only song based on Goethe's poetry, in which a stanza structure is used. But it is unlikely that he wanted to write the song, imagined by the poet - quasi-folk "Volkslied". Here we come across the very dense harmonic structures and very solitary and lively part of piano accompaniment. The slow tempo (Langsam), the gusty Schumann's three-beat meter (3/8), the "non-square" five-beat instrumental introduction and the "passionate" f-moll tonality perfectly characterize the overall character of the work. The vocal part is very demanding, intonationally and tessiturally complicated. In it the agitated, two-beat, phrases-questions with up-beat predominate. This enhances the modality of the question genre. From the 14th beat (B-Dur) the musical phrase-question grows ( $14-17$ beats: as if run-up before the main appeal-call). Then again, there is a two-beat question-"run-up", which leads to the culminating zone of the stanza on the words of the emotionally charged call "Dahin!" (the culminating five-beat phrase-call in beats 20-24) and the final three-beat post-call (25-27 beats), ending the stanza. The final phrase blends in closely with the further flow of music (the interlude-link between the first and second stanzas, which is a repetition of instrumental introduction) by means of "invaded cadence" and it plunges us in the further development of the artistic plot in the second stanza. Similarly, the third stanza of the composition is created, and only the final postlude, while subsiding, is shortened by half. Gradually, in the work the partner expressive spheres of voice and piano are mixed, and the vocal acquires exquisite features of Schumann's instrumental melodics. The genres of expression become of the same type, containing a one-level nature. Thus, a "simple folk song", according to Goethe, remains in this work an unattainable ideal, and the sincere emotions of Mignon are irrevocably lost.

P. Tchaikovsky's "Mignon's Song" (based on the text of a verse-replay) is created in the style of a detailed lyrical romance with a sufficiently developed instrumental component in the introduction and code (identical in music) of the works. This creates the framing, which first introduces the listener into the emotional character of composition, and in the end summarizes the unity of all emotional content of the work. Here dominate the descending motives of sighing, emphasized by the vivid syncopes (intonation of two descending tones: for a second or tertiary down). This 
mood of nostalgic appeal-complaint after the introduction of the melody of the voice is completely dispelled, changing by a series of interrogative phrases of utterances, which against the background of active sequential development lead us to the first climax (the 17th beat with the delayed pause). Further, according to the poetic script, appeals ("Dahin!") are introduced. Because of their intonational passivity (rather impersonal sequencing of the second movement), they are perceived, to some extent, theatrically and not quite sincerely. Mignon's mood of emotional nostalgia and fragile excitement somehow disappeared in the usual sequences of small melodic phrases (the winning, light and joyful tonality of Es-Dur work can serve as another argument). The romance itself is written according to the laws of this creative genre, with domination of vocal melodics against the background of "guitar" accompaniment and very close to the style of romantic opera arioso. In general, P. Tchaikovsky's "The Song of Mignon" became, at the very least, a song and almost an alternative version of the same plot, which was proposed by Goethe in his poetry.

In Hugo Wolf's version, "Mignon" is less associated with the primary source than in the work of R. Schumann. Wolf, for example, emphasizes the word "hoch" (high) with the top of the melodic phrase, and the word "glühn" (to shine) is enhanced by changing the melodic pattern by means of bringing the melody an octave down and thereby achieving a warmer, more radiant timbre. The smallest emotional nuances of the poetry melody are meticulously reflected in the sound-high configuration of the vocal melody and the very ground harmonic development with numerous deviations and modulations in the distant tonality. Unfortunately, the complexity of melodic development and harmonic structures sometimes leads to the loss of harmonic unity, which is reflected in the artistic integrity of the work and the conviction of its concept when heard. In terms of the use of speech genres in such a compositional approach at the highest level the emotional narration dominates. Constantly changing, in its bosom the genres of the lower levels appear - the question and the call (which are modeled by the same melodicand-rhythmic means against the background of the texture of accompaniment active change). An interesting finding of the composer, which allows to detail the modalities of the genres used, is the use of a strophic form with a unique (or similar in general outline) intonational-andrhythmic beginnings of the verses. This brings the musical-and-poetic expression to the intonation of excited emotional narration within domination of the narration speech genre. Also, H. Wolf's song is perhaps the only composition in which the last lines of the first two stanzas are presented, as in the poems, in the genre of explanation, and the last two lines of the final stanza very close to the poet's intention model the traits of callrequest genre, used by him. The integrity of the concept and the 
completeness of the form of this song is significantly facilitated by a kind of "ingrowth" of the music of the initial four-beat piano introduction to the final beats of the song (with a vocal part already).

We can see that each composer who tried to put on music "The Song of Mignon" followed the same creative instructions, but each realization has many subtle differences. In L. Beethoven's interpretation we find a firm understanding of the fluidity of the emotional lyrics of the poems and the subtle meanings of the lexemes. In Liszt's works, the dissonant harmonies and intonational interconnections between the voice part and the piano accompaniment create a tremendous emotional drama, enhanced by the subtle interweaving of instrumental texture lines and timbre units into rhythmically and intonationally designed vocal line. The musical-and-poetic version of Franz Schubert, perhaps the most famous one among the best known nowadays, shows the great influence of Beethoven's version, and is probably the closest one to Goethe's creative intentions. The musical-andpoetic work of Ludwig Spohr, due to the change of the dominant musicaland-speech genre, "replays" the lyrical poetry in an epic format, effacing the emotional strophicity and emphasizing the features of historical narration. Robert Schuman's version demonstrates a lot of lively accompaniment of a saturated texture with a lack of real emotional connection to the title character of the poetry: it is actually a tremendous appeal that is created due to the continuous alternation of short appeals-questions, questions-calls and their combination at the lower levels.

P. Tchaikovsky's "The Song of Mignon" has little to do with Goethe's precedent text both in terms of content and genres used (speech genres and creative ones: romance, arioso). Obviously, the main reason for this lies in the verbal text-replay, which directly formed the basis of the composition. Hugo Wolf's version of the song uses rich possibilities of the texture and harmony, as well as "listening into" the specifics of word-formation, to offer the listener a beautiful song that, unfortunately, has little to do with Mignon's singing. Probably, Wolf turned out to be the closest to the synthesis of music and poetry that, in Goethe's view, could best convey the deep meaning of the song. From the point of view of music-performing practice in the twenty-first century, the most beloved was the version of Franz Liszt (both in the first and third editions). In fact, it shows more genuine emotions than all the rest. Being difficult enough for interpretation because of its significant musical-and-expressive as well as technical complexities, it is considered by performers and musicologists to be one of the finest versions of this song. Anyone who decided to perform "Kennst du das Land?" (or any other Mignon's text) should take a lot of time and effort to grasp the character's inner self and make sure that he reflects her / his fragile vulnerability and emotional sophistication as best as possible. This 
delicate elegance is perfectly embodied in the compositions of Beethoven, Liszt and Schumann. Musicians (singers and accompanists) are most often aware of their obligement to be responsible for a musical component of the work, but often they are not obliged to be responsible for the text, without being fully aware of the reasons for any or all imperceptible differences in its musical reading.

\section{CONCLUSIONS}

In fact, as we have tried to show, one of the main means of changing the composer's expression is an adequate selection of music-and-speech genres, their stratification onto different levels, and a more or less successful combination with the speech genres of the poetry. The criteria for the successful or less successful use of these latter and the artistic persuasiveness of certain combinations lie at the intersection of the spheres of musical aesthetics, artistic taste and artistic communication; and the scientific study of these issues has just begun. Therefore, at the end of the presentation, I think, it is appropriate to quote the well-known expression of the famous American composer and musical critic, Pulitzer Prize winner Virgil Thomson: "If the songs really need words (as it really is, since a human voice without them is another instrument for the wind), then in the marriage of words and music there must be basic compatibility, which seems to dominate in this union of the exact form of the text and the purpose of the utterance".

\section{SUMMARY}

In the article it is proven that the dependence of readable content of musical compositions depends on verbal precedent texts laid down in the basis of works. This uses reliance on the plurality of content based on the variability of the speech-genre interpretation. Also, the development of issues of the functioning of speech genres in music is proposed in connection with certain aspects of the theory of precedent and issues of the cooperation of speech genres in verbal and musical language.

The basis of the researchers' reasoning was the similarity of the process of constructing the contents of the works of art in literature (poetry) and music on the basis of the precedent texts and utterances used. The mechanisms of strengthening or elimination of a number of meanings by emphasizing certain moments of utterances, or certain names (precedent utterances and precedent names) by musical or verbal means have been studied. The dominant means of expression are the syntactic resources of constructing the utterances and their associations at the higher levels of musical works. These means and their potential in the process of speech 
genres reading, which are the basis of musical and poetic interpretation of works, have been pointed out.

The regularities of intonation dominance and syntactic division of verbal utterances in the process of formation and correction of the contents of musical and precedent poetic works have been analysed. The interaction of means of constructing the musical and verbal expressions in such works have been traced. The role of individual-and-stylistic features of thinking of the authors of musical utterances in the described processes have been revealed.

For maximal reliability and objectivity of the study, the only one wellknown and undeniably artistically perfect precedent verbal-poetic text in various musical readings has been used - "Mignon's Song" by J. W. Goethe. For persuasiveness of the stylistic parameters of the analysis, the musical and poetic versions of "Song", which were made public in the XIX century, have been used.

\section{REFERENCES}

1. Беліченко Н.М. Структурна поетика музичного твору (на матеріалі музики сучасних композиторів 80-х років. Автореферат дисертації на здобуття наукового ступеня кандидата мистецтвознавства. Київ, 1992.

2. Гудков Д.Б. Прецедентное имя и проблемы прецедентности. Москва : Издательство МГУ, 1999.

3. Драч И. Странствия Миньон. URL: http://jgreenlamp.narod.ru/ minjon.htm.

4. Караулов Ю.Н. Русский язык и языковая личность. Москва : Наука, 1987.

5. Кузьмина Н.А. Интертекстуальность и прецедентность как базовые когнитивные категории дискурса. Медиастилистика. Вып. 1. URL: www.mediascope.ru/node/755.

6. Слышкин Г.Г. Линвокультурные концепты прецедентных текстов. Москва: Академия, 2000.

7. Слышкин Г.Г От текста к символу: лингвокультурные концепты прецедентных феноменов в сознании и дискурсе. Москва : Академия, 2000.

8. Сорокин Ю.А. Психологические аспекты изучения текста. Москва : Наука, 1985.

9. Сюта Б. Взаємодія жанрів вербального і музичного мовлення в контексті інтермедіальних атракцій. Intertextualita a intermedialita: $v$ prostoru ukrainského jazyka, literatury a kultury. Alla Arkhangelska (ed.). Olomouc : Univerzita Palackeho v Olomouci, 2018. S. 243 - 264. 
10. Сюта Б. Жанри музичної мови: постановка питання. Українське музикознавство. Вип. 38. Київ : НМАУ імені П.І. Чайковського, 2012. C. $138-159$.

11. Сюта Б. Мовне поняття жанровий тип у термінологічному корпусі теорії музики. Současné slovanské jazyki a literatury: tradice a současnost. Alla Archangelska (ed.). Olomouc, 2014. S. 159-167.

12. Хаминова А.А. Теория интермедиальности: проблемы и перспективы. Мова і культура. Вип. 15, т. 7. Київ, 2012. С. 373-379.

13. Шип С.В. Музыкальная речь и язык музыки. Одесса, 2001.

14. Agawu V.K. The Challenge of Semiotic. Rethinking Music. Oxford: Oxford University Press, 1999. P. 138-160.

15. Arbogast J. A comparative analysis of Mignon's song Kennst du das Land. A creative project paper submitted of partial fulfillment of the requirements of candidacy for the degree of master of music with a major in vocal performance. Ball State University, 2008.

16. Hatten R.S. Interpreting Musical Gestures, Topics, and Tropes: Mozart, Beethoven, Schubert. (Musical Meaning and Interpretation, Robert S. Hatten edition). Bloomington and Indianapolis, IN: Indiana University Press, 2004.

17. Siuta B. Speech Genres of Music // https://www.academia.edu/ 10229024

18. Wierzbicka A. Genry mowy. Tekst $i$ zdanie. Wrocław - Warszawa Kraków - Gdańsk: Ossolineum, 1983. P. 125-137.

19. Wolf W. Intermedialität: Konzept, literaturwissenschaftliche Relevanz, Typologie intermedialer Formen. Selected Essays on Intermediality by Werner Wolf (1992-2014): Theory and Typology, Literature-Music Relations, Transmedial Narratology, Miscellaneous Transmedial Phenomena. Leiden : Koninklijke Brill nv. P. 173 - 212.

Information about the author: Siuta B. O., Doctor of Art Studies, Habilitated Professor, Prorector Kyiv Academy of Arts 10, Heroiv Stalinhrada Avenue, Kyiv, 04210, Ukraine 